\title{
Representation of Patriarchal Culture in New Media: A case study of News and Advertisement on Tribunnews.com
}

\section{Dr. Bertha Sri Eko Murtiningsih}

\author{
Maria Advenita G. E. \\ S. Ikom \\ Multimedia Nusantara University, Tangerang, Indonesia
}

\section{Doi:10.5901/mjss.2017.v8n3p143}

\begin{abstract}
Patriarchal culture has become the dominant issue in online media. Recently, online news and advertising media have less gender perspective. Its content tends to position women as marginalized subjects receiving negative stereotypes. This study aims to review women's reality in online media, in the form of: 1) news published on tribunnews.com; 2) how women issues are presented by using gender perspective journalism. This research uses descriptive qualitative content analysis approach combined with discourse analysis method of Sara Mills with a focus on the position of the subject and the object. Tribun daily Media in its online form (www.tribunnews. com) is the locus of this research. Tribunnews. com is selected because it ranks in big three news portal in Indonesia, having an extensive and strong network as they are supported by more than twenty regional press. The results show that media has not been fully able to raise women's issue in the mainstream. The media still portrays women within the bond of patriarchal culture, discrimination, and consumeristic lifestyle. The power of patriarchy dominates the news which marginalizes women. News content and its features follow the pattern of male dominating power. Tribunnews.com has been legitimizing gender bias by accepting exploitation on female's physical appearance as normal and acceptable. In other instances, Tribunnews.com does not highlight intellectual and leadership values of women as actors. News in online media should be reformed to be more gender sensitive.
\end{abstract}

Keywords: Patriarchal culture, Online Media, Stereotypes, Discrimination, News text, women position, gender perspective journalism

\section{Research Background}

Indonesian society in general still adheres to patriarchal culture. This particular type of culture is embodied in every aspect of life and is typically socialized through religious teachings, embedded values in family, codes of conduct in organizational and employment settings, as well as in the lines of formal, informal and non-formal education. The patriarchal culture renders difference between the role, position and significance of men and women, both in private and public sphere. With regards to the role played by media, it is easy to observe that media organizations tend to employ more men than women. The place and significance of women's voices are lacking in media setting and organizations, such as decision maker's positions. As a result, women's voices are underrepresented in media. Mainstream media tend to treat women in unequal standards, both in terms of quantity and quality, compared to those of men. News, advertisements, and articles published in media quite often portray women in negative light and unfortunate stories.

Nowadays, gender stereotypes in new media are on ascendancy. The emergence of typical news and advertising which promote gender biases are quite rampant. Messages of gender equality in new media are simply hollow, let alone discriminating against women. These factors contribute to the enlargement of women's position as second class in society.

Some scholars observe that media is able to represent reality or even transform reality. Representation contains "a second meaning." Fourie (2007) asserts that "media plays an important role in the process of representation" (p. xxv). 
The history of media and media relationship with structures in society such as politics, economy, and culture, has been discussed extensively by communication (and sociology of communication) scholars for the last five decades, such as McLuhan (1964), Halloran (1973), Schudson (1981), Marvin (1988), Lowery \& DeFleur (1995), Wang, Servaes \& Goonasekera (2000), Lievrouw \& Livingstone (2006), Fourie (2007), Scannell (2007), Staiger \& Hake (2009), Castells (2010), Valdivia (2013). Most communication researchers involved in these related issues believe that media tend to portray people, groups, organizations, and topics in structured, stereotyped, and, quite often, ideologically predisposed ways. These particular types of portrayal then constitute the symbolic power of media. The concept of representation and symbolic power of media are two salient tools to use for our critical understanding of how media works.

Media text never simply presents the world in direct manner; they are always representing reality according to their selected filters. Media is constructing reality. The reality of the world presented is the result of media construction, deliberately committed by certain people or group, based on their views. In other words, media represent their views by repeatedly presenting certain images, stories, situations perceived to be natural and familiar.

Based from the context of media situation in Indonesia, the representation of women in media seems to reinforce the perception that women are portrayed negatively and in marginal position. News about women is largely influenced by patriarchal views. While woman is increasingly perceived as occupying a second class social status, media also lacks the power of sounding gender equality. Thus, woman bears the burden of stereotyping as consumeristic, materialistic, too demanding, not independent and weak being. At the other spectrum of media, woman is quite often portrayed as the object of views and desires of men, which is the main cause behind gender-related social problems such as prostitution, harassment, rape, and violence. These depictions of woman as such would later reinforce more acute stereotyping against women.

The classic study of the image of women in the media, especially advertisement in women magazines, has been performed by Tomagola (1992). This study employs a qualitative content analysis approach. The results show that there are five basic images displayed by advertising in women magazines, as follows: First, Frame image. This image emphasizes the importance of the middle and upper class women who looked attractive. Therefore, women should emphasize womanhood biologically; Second, Pillar image. This notion depicts women as the primary householder; Third, the Contest image. Here, women are treated as objects of gratification of men; Fourth, Pinggan image. This notion identifies women with the kitchen activities; Fifth, Inter-communication image. By this, women must be able to maintain their performance to be accepted in their society. Women are construed to be physically presentable.

The presence of New Media in contemporary media studies and discourse reinforces the position and stereotypes about women. Media's biased portrayal of women plays an important role in confirming, spreading, and socializing differences and gender inequalities through multi-layered channels of information. According to Yusuf (2004), "media construction is typically considered correct and the reality of media's presentation is accepted as something normal." ( $p$. 354). If media negatively labels women as weak, consumeristic, and not independent figures, then such biased portrayal of women will easily be accepted by the public.

New Media has also changed the style of journalism, such as the rise of online journalism, where facts, information, and reports are produced and distributed through internet. News in New Media era is enabled to spread more widely and rapidly. News content is now enriched by lots of digital elements such as moving images, hyperlinks, embed videos, comment box. These elements make the information presented becomes more attractive. One of the salient characters of online journalism is its dependency on speed in delivering information. Its use of sensational headlines to attract readers is also part of online journalism tenets.

Taking all sources above into background account, this study will analyse and review the construction of women in online media, especially on Tribunnews.com. The reason behind the selection of Tribunnews.com as locus of research will be detailed in section 4.a. below.

\section{Theoretical Perspective}

\subsection{Representation}

Representation is a term used to indicate the description of groups and social institutions. According to Sutrisno and Putranto (2005), "representation is a practice of giving and an act of disclosure of the significance of the object or practice in the 'real' world. It is also understood as the impact of 'representational' because signs do not stand alone outside of the object, nor do they reflect the direct object (like a mirror)." (p. 282).

The process of representation is highly related with meaning and language. As expressed by Sturken and Cartwright (2001) "Representation is the use of language and images to create meaning about the world around us. The 
world only has meaning and can be seen through those systems of representation." (p. 12)

The concept implies that representation refers to the specific use of language and images, namely to render meaning about reality as such ('the world around us'). The language is used as far as it helps us to describe, understand, and explain the world that we see. This process occurs through the representation of visual language in media, wherein it has rules and conventions of how they are organized.

Meanings produced by the individual are parts of representation. Media helps to represent about the world and aids individuals to understand reality. The reality is often considered as a truth. Representation in the media is not only related to what is shown by the media, but also related to the meaning, which was constructed behind its representation. Media text is constructed to represent the reality of the world. As often the case, representations are ideological by nature; they tend to give a partial and selective view of reality in order to maintain the power of certain groups.

Confirming Sturken and Cartwright statement above, Branston and Stafford (2010) assess that:

"Media text never simply presents the world direct. They are always a construction, presentation. They are constructed by people or groups deliberately. They are not a mirror of the world but a version of the world, a constructed one. The media represents, over and over, certain images, stories, and situations. This can make them natural and familiar." ( $p$. 106)

Gender representation in media reflects certain constructed reality and its constructed reality is the result of various thoughts and decisions made by media workers. Internal and external organizational factors of the media involved will influence the construction of reality as such.

On the issues of gender representation, the higher number of male employees, compared to female counterparts, the more it will affect how women are performed. Media culture is still undeniably patriarchy where men have crucial roles and positions to determine the outcome of their ideological biases. This patriarchal power will indisputably dominate the content of media products and organizational setting. This situation leads to media coverage which put woman not as an actor, farther less an agent of social change, but simply as a subordinate entity.

\subsection{Issues of Gender, Patriarchy, and the Mass Media}

In her seminal book, The Second Sex (1949), Simone de Beauvoir, a leading feminist thinker, proposes a challenging statement to patriarchal culture surrounding her, "On ne nait pas femme: on le deviant" (One is not born, but rather becomes, a woman.) (p. 330). Butler in Fallaize (1998) highlights the difference between sex and gender (p. 30). According to Beauvoir (1949), "Man's 'anatomical destiny' is profoundly different from woman's. Their moral and social situations are no less different" (p. 443). While sex is an anatomical distinction that separates between women and men, gender is a cultural meaning that shapes understanding of the body.

Handayani and Sugiarti (2001) later affirm that "sex differentiates men and women in biology's term. Male and female is separated biologically for the things attached to their body for a life time." (p. 3). The case is different with gender, which is socially and culturally constructed. Gender distinguishes men and women based on the values established by society. Gender differences will produce different functions and roles for each category of sex in different areas of life.

Gender differences arise from the process of social, cultural, and psychological struggle. It is promoted and legitimized through religion, education, culture, and even ideology of the state (Yusuf, 2004, p. 352).

Mosse (1996) says that "fundamentally, gender and biological sex is different. Biological sex is a gift. A person is born without being able to choose to be male or female." (p. 2) However, factors that make a person has masculine or feminine character are combination of building blocks of biological base, as well as the result of biological interpretation by the culture where one was born.

Table 1: Terms of differences between Sex and Gender (Bhasin in Sarwono, 2013, p. 49)

\begin{tabular}{|l|l|}
\hline Sex & Gender \\
\hline Natural and purely biological & Cultural, social, and man-made. \\
\hline $\begin{array}{l}\text { Referring to real difference of genitals, also } \\
\text { related with birth function }\end{array}$ & $\begin{array}{l}\text { Referring to responsibilities, roles, patterns, behaviours, and qualities. The } \\
\text { character is masculine and feminine }\end{array}$ \\
\hline The character is fixed, anytime and anywhere & The character is not fixed (dynamic). It depends on time, culture, and even families. \\
\hline
\end{tabular}

Gender construction, in its development of the term, is then regarded as natural as sex. The construction of "Feminine" is 
attached to women while "Masculine" is to men. A woman who is not feminine and man who is not masculine then considered as a bad person.

According to Soemandoyo (1999), gender ideology gives negative aspect to the formation of patriarchal structures (p. 60). It means that patriarchal structures put women position and significance lower than men, or, in other words, the existence of male domination against female. Patriarchy concept developed by Wilson (in Walby, 1990) even further claims that (patriarchy is) "a system of social structures, and practices in which men dominate, oppress and exploit women" (p. 214).

The patriarchal structure in mass media is embodied in the organizational structure in which the composition of the journalist workers is unbalanced: the number of men is more than women. To further the case, men have more important positions and clusters of authority in decision making. These conditions affect the production of news-reporting about women which tends to be unfair. The imbalance structure between journalists working women and men in mass media management of workers composition will further influence the orientation of news content. The non-representative numbers of women in media put women in marginalized position.

For example, in media coverage of rape, quite often women are considered as the object and the trigger of the problem. Women are used as interesting objects in news related to sex and pornography (Soemandoyo, 1999, p. 670). This acute observation is then supported by Awuy's opinion (2000), who confirms that the world of journalism becomes the central site of patriarchy since the important position as editor in chief is generally dominated by men (p. 241).

Within the context of mass media related to gender issues, Soemandoyo (1999) believes that media construction of gender has an important role to influence people's behaviour and culture (p. 61). In one side, the media is able to become an agent of change. On the other side, it can impede change

\subsection{Gender Journalism}

Media are channels of information distribution and dissemination. It may also strengthen certain values, including values of gender (in-)equality. Normatively speaking, media should give more space to strengthen the process of gender equality principle which is embodied in media content, including news, features, or advertisement published.

The media should begin this process to implement gender perspective journalism. According to Subono (2003), journalism with a gender perspective is an activity or practice of journalism which largely informs or even questions, and continuously being critical towards various forms of media which hinge on the unequal relations between men and women (p. 363)

To highlight the gender dimension in journalism practices, Kafiris (2005) poses some critical questions to detect sensitivity of the news to advocate or undermine the importance of gender (p. 74), as follows:

1. Language: Is a neutral term used? Is the assumption about people based on gender? How do they mention women?

2. Angle of the Story: See the story from whose perspective? Who is included? Who is excluded?

3. Context: Is the story bringing the context so that readers can build their own thoughts?

4. Source: How many resources are women? How many of them are minority?

5. Visual: Is the image contrary to the content and associated with the title as well as the text?

According to Yusuf (2004), the development of gender-sensitive journalism is divided into three levels, namely: the level of cognitive, organizational, and technical skills (p. 364). These levels is summarized in diagram below:

Table 2: Three levels of gender-sensitive journalism

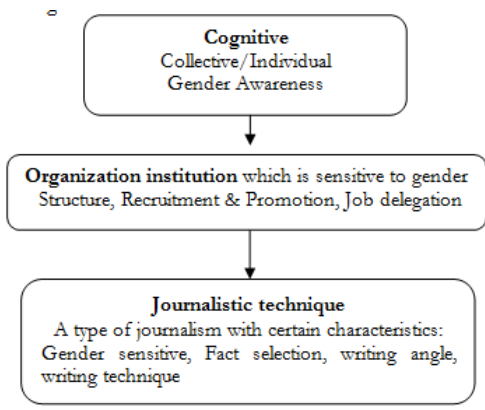


According to Subono (2003), there are two major approaches in journalism, that is, seen from a neutral or objective approach and seen from a gender perspective (pp. 61-64). In Table 3 below, the Gender Perspective Journalism will be highlighted with three inter-related variables involved, namely: facts, media position, and journalist position.

Table 3: a gender perspective Journalism

Facts:

1) Basically, the existing fact is representation of dominant culture of the society

2) News is a reflection of the interests of the dominant forces as a result of gender inequalities and injustice. It highlights the dominant economic-political and social force that has created inequalities and gender injustice.

\section{Media Position:}

Considering that in general media is controlled by dominant (patriarchy) interest, thus media should be a means to set free and empower marginal group, especially women

\section{Journalist Position}

1. Journalist' values or ideology could not be separated from reporting process and news reporting,

2. Journalist has a role as an activist or active participant of marginalized groups, especially women in the community,

3. Ideology as foundation of moral (ethical) for journalist,

4. Professionalism as a control mechanism,

5. The purpose of the news reporting and writing: partiality and empowerment for marginalized groups, especially women,

6. Journalist is a worker who has different position in social class.

\section{Aims of Study and Research Method}

This study uses descriptive qualitative approach combined with discourse analysis method of Sara Mills. Mills focuses her insightful attention on feminist discourse related with how women are portrayed in various texts, either in novels, photographs, or news. Drawing on the work of Smith (1990), Mils (1997) affirms that "discourse (is) less as something to which one is subjected than as a vehicle which is used by subjects to work out interpersonal relationships, complying with certain elements and actively opposing others... texts are not somehow divorced from social contexts and individual participants simply because we analyse them in terms of their discursive structures. (p. 85)

Feminist Discourse's point of view is to show how the text is biased in portraying women. Women are frequently portrayed in text as the ones to blame, excluded, in lower position, compared to male subjects, as seen through the lens of Eriyanto (2011, p. 199).

This study will limit itself to only reviewing about the position of subject-object, about how one party, group, person, idea, or event is displayed in a particular way within the discourse of the news that eventually affects meaning(s) when received by the audience. This limitation is drawn from Mills's (1997) belief that early version of simple femininity is "an imposed ideological category and which thus tended to cast women as passive victims of oppression" (p. 86), as well as where the position of the object and the subject in this representation contains certain ideological assumptions.

Researchers will analyse the actors involved in several corruption and rape cases, in which five news text are selected. This research will address who is positioned as the subject (narrator). Through an analysis of the factors involved, the readers will know the detailed description of women and their subject-positions in that event. Researchers will also review on how the reader is placed in selected criminal and rape news.

Table 4: Research Instrument based on Sara Mills' Feminist Discourse Theory

\begin{tabular}{|l|l|}
\hline Level & Description \\
\hline Subject-Object Position & How an event is viewed and from who(m)? \\
\hline & Who(m) is placed as a narrator (subject)? \\
\hline & Who(m) is placed as an object of the narration (object)? \\
\hline Position of Writer- Reader & How is a reader position performed in the text? \\
\hline & How is a reader place him/herself in the text? \\
\hline & To which group does the reader identify him/herself? \\
\hline
\end{tabular}

The unit of research analysis is selected news text and advertising images in daily online Tribun (www.tribunnews.com). Selection of the news is using purposive sampling technique. Texts selected are texts containing coverage about women 
in social, political, and criminal cases of rape and sexual harassment, as well as advertisements.

Data collection techniques are conducted by collecting literature data and some news published in tribunnews.com which shows gender bias. The numbers of reports analysed are eleven news, published in 2010 (1 news), 2015 (9 news) and 2016 (1 news).

\section{Results}

\subsection{Tribun Daily}

Tribun News (http://www.tribunnews.com/) is an online news portal launched on March 22, 2010, aggregating several local and regional news portals, managed by Tribun Network. Tribun News is trying to raise local perspective(s) and address national, regional and international interests, with tagline "The National's Local Newspaper." Tribun News' mission is to build healthy and clean information business by developing the principle of professionalism in press business, in journalism and news reporting.

Tribunnews.com is managed by PT Tribun Digital Online, a subsidiary of Kompas Gramedia group. Its headquarters is located in Jakarta. This news portal offers several canals, including national, regional, international, sport, business \& economy, politics, health, celebrity and lifestyle. It also manages online discussion forum, as well as online communities through social media such as Facebook, Twitter, and Google+.

Backed up with Jakarta-based reporters, TRIBUNnews.com's strength principally comes from its 28 regional newspapers---previously known as Persda, but since March 22, 2010 changed into Tribun Network---as local partners and almost 500 journalists located in 22 important cities across Indonesia.

According to Alexa Traffic Statistics (http://www.alexa.com/siteinfo/tribunnews.com), in March 7, 2014, at 13:38 WIB, Tribunnews.com sat at No. 3 news portal just behind its senior detik.com and kompas.com, but still higher than viva.co.id and merdeka.com (http://www.tribunnews.com/nasional/2014/03/07/tribunnewscom-portal-berita-no-3indonesia). Tribunnews.com currently holds No. 142 in Global Rank and Rank ${ }^{\text {th }}$ in Indonesia1.

Tribun News applies the concept of "Market Driven Editorial Policy"2 as a business strategy in order to reach the level of viable economy and to carry the torch of ideal role as agents of change. Having built its noble reputation through the existence of its previous version, Persda (Pers Daerah AKA Local and Regional Press), Tribun News is not solely oriented on market demand with a taste of society's interest, just to get it "sold out". Tribun News builds a good taste of enlightened culture in order to conform to the ideal goals and roles of the press.

Tribun News has target readers as follows: 1) men and women, aged 24-29, residing in capital cities across Indonesia, city-satellite towns and city-districts, coming from middle, upper-middle and upper socio-economic statuses; 2) the targeted readers are assumed to have metropolitan lifestyle, paying attention to variety of lifestyles' choices, and fond of changes; 3 ) the targeted readers are also white-collar workers, mid-level workers, and decision makers. It positions itself as an independent, credible, and friendly media promoting benefits of reading newspaper, such as easy and entertaining reading as well as values-oriented customers.

\subsection{Selected News from Tribunnews.com seen from the perspective of Quality Content and Gender Perspective:}

\subsubsection{Cases of raping and sexual harassments}

In several cases of raping reports, news and comments often put women as subordinate and the ones-to-blame subjects, but more lenient towards the rapist itself. For example, below are the provocative headlines which victimize women:

- The hymen of a student as rape victim of a couple remains undamaged (Tuesday, August 11, 2015

- Junior High School Student is sexually abused by 6 youth all night long, and directly driven to school next morning (Friday, March 4, 2016)

- A Rapist Suspect of a Junior High School student: I was just told to feel it, they said she is a 'bitchy' teen (Wednesday, Februari 11, 2015)

\footnotetext{
1 Data accessed on Monday, April 17, 2017, at 9.35 WIB

${ }^{2}$ Based on the author's personal interview with Mr. Herman Darmo, Director of Regional Newspaper Group (Tribun Network), on April 5, 2016
} 


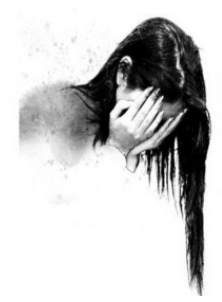

Fig. 1: A Crying Girl (http://cdn2.tstatic.net/belitung/foto/bank/images/ilustrasi-foto_20151006_122034.jpg)

Patriarchal-based sexist language is often used by the reporters (and also, editors) in rape stories. The choice of word such as "digilir" (repeatedly raped by few men) gives connotation of male superiority. In fact, the perpetrators of the rape are masculine figures (Yusuf, 2004, p. 362).

Lack of empathy is the reason behind careless diction. Thus, the media forms the opinion that the woman triggered the rape. As written in one of the headlines above, "I was just told to feel it, they said she is a 'bitchy' teen" (Tersangka Perkosaan Siswi SMP: Saya Hanya Disuruh Ngrasain, Katanya Dia Cabe-cabean"), the suspect was instead 'framed as a victim' with the words choice 'saya hanya disuruh ngrasain'. The woman as a victim here is not represented. The headline also labels 'cabe-cabean'3 for the victim of the rape. It is clear from the headline that the woman here is positioned as the cause of the case.

\subsubsection{Cases of Corruption}

Furthermore, in cases of corruption mentioned below, the articles also put women in marginalized positions and label them as the cause of the problem.

i) Corruption and Women behind Corruption (Thursday, July 23, 2015)

- The title and the content of this news give impression that women are the cause of corruption.

ii) Women in Corruption Maelstrom (Tuesday, November 17, 2015)

- In Aceh, female figures working as civil servants, employees of enterprises and banks, actively involved in corruption cases. Some may believe that women are plunged into corruption maelstrom because of their socialite lifestyles, such as wanting luxurious cars, expensive handbags, branded clothes, shoes from Italy, etc.

- Corruptors often use illegitimate wife to pool the money from corruption. (Monday, April 27, 2015)

- Women are quite often being victimized in corruption cases because the culture prohibits them to ask the source of their husbands' income. Also, by not asking, they avoid potential conflict with their husbands.

\subsubsection{Image of women as sexual objects in commercial advertisements:}

According to Bemmelen (1992), the portrayal of women as sexual objects for men is used to serve the taste of men, or what is considered the taste of men by media, with specific goals to entertain men and to increase the attractiveness of advertising displayed (p. 62).

Tribunnews.com journalists quite often use both sensational and bad taste writing to attract the attention of readers and to zoom the advertising, such as:

i) "The Large Breasts of British Woman Almost becomes Lethal Weapon" (Tuesday, August 10, 2010)

The sensational headline used female vital body parts in order to attract as many readers as possible, mostly male readers, and to increase the page views. This following ads also uses the same 'trick', with female visual image on the zoom.

ii) Wanna date a pretty lady by riding on exotic car? (Monday, May 4, 2015)

\footnotetext{
${ }^{3} \mathrm{~A}$ current Indonesian slang term which is synonymous with 'bitch' in Western term.
} 


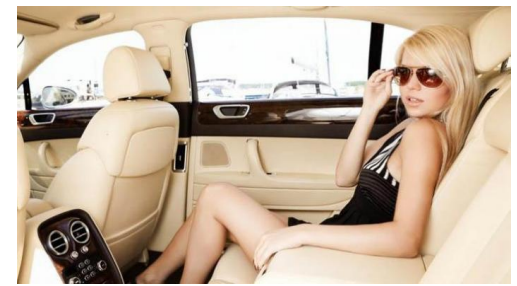

Fig. 2: http://static6.depositphotos.com/1062035/625///950/depositphotos_6259299-stock-photo-lady-in-a-luxury-car.jpg

In promoting dating site (supercardating.com), the content of the article highlights woman physical appearance, her beauty, and her craving for luxurious lifestyle, instead of her other qualities making her worthy more than physical appearance.

\subsubsection{Image of women in politics}

Moving to a rather serious affair and politics, smart woman is also portrayed by her physical beauty.

i) 'This Beautiful Woman asks Jokowi to Response on Cigarettes Danger" (Sunday, Februari 15, 2015)

The news, discussing a stricter demand against tobacco, begins with description of woman physical appearance, as reflected in the title and first paragraph, "Amaliya Sharfina stands out among the crowd of people who do exercises near Hotel Indonesia roundabout (Bundaran $H I)$ on Sunday (02/15/2015). This beautiful woman urges people to quit smoking for the sake of public health."

The choice of words in the news implies that Amaliya deserves attention and worthy to be reported not because of her intellectual quality and/or political stance, but merely because of her beautiful physical appearance that could be addressed as sexual object.

Depiction of women in political news also tends to negatively stereotyping, such as behaviour in the past or some eccentric hobby. Here is the example:

ii) Smoking and Having Tattoos, Susi The Minister Lady is still the Most Favored in Public Eyes (Monday, October 26, 2015)

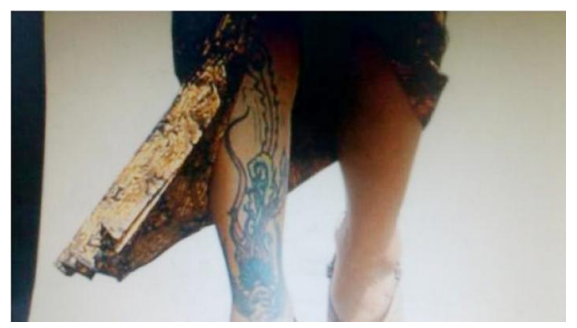

Fig. 3: http://cdn2.tstatic.net/makassar/foto/bank/images/tato-menteri-susi-pudjiastuti.jpg

\subsubsection{Image of women as migrant domestic workers}

The use of gender insensitive journalism language quite often reflects gender inequality. The use of euphemism and dysphemism mostly discredits women (Siregar, 2000, p. xiii). The use of gender insensitive journalism language still appears in this saddening news about Indonesian migrant domestic worker in Jordan.

i) Saerah, the beautiful TKI from Grobogan, was beaten to death by her Master in Jordan (Saturday, August 22, 2015)

As the news run, Saerah, a migrant domestic worker (MDW) from Central Java (Indonesia), died after being beaten to death by her master in Jordan. In the article, woman's physical appearance is highlighted by the use of words 'beautiful migrant worker' and' flawless widow'. Unrelated to the nature of the news, the image of woman portrayed here is double-victimized. 


\subsection{Subject-Object Position}

The headline news mentioned above, "The hymen of a student as rape victim of a couple remains undamaged" (Tuesday, August 11, 2015), tells a rape committed by Gama to the student. On the first lines of the news, it appears that the perpetrator of the rape is positioned as the subject (narrator), while "WW" as the victim is placed as an object (of rape). The incident of rape, the process, and the rapist himself are identified by the reporter from the information given by WW. The news, later on, puts WW as a storyteller. As a result, the rape is told in actor's perspective, thus the incident of the rape puts WW in marginalized position, and, contrary to gender perspective, puts Gama as the subject. This gives Gama an advantage.

News text begins with the sentence: "Twenty years old Malang university student from Kediri, with the initial of WW did not suffer hymen damage after being drugged, tortured and raped by a couple, Gama Mulya (24) and Suci Anin Nastiti (20)." This sentence confirms that Gama, a male figure as the rapist, aided by Suci Anin, committed the rape, but their acts did not damage the hymen (symbol of virginity) of the victim (WW). By phrasing it in such manners, readers are led to be sympathetic with the rapist instead of the victim. The problem of the rape case here is seen physically (by mentioning 'hymen') rather than psychologically (a very traumatic event for the victim). The victim's feelings regarding the incident are not reported by the reporter. In this case, the condition of the victim is out of concern.

The whole news above poignantly illustrates how the position of subject and object of storytelling will determine how the text is presented. News text is highly gendered, because the rape case is only seen from male point of view. The presence of the woman as victim is not only overshadowed, but her real presence is even performed (narrated) by a man. In this text, the woman has always been the object, seen, and poorly represented.

Sara Mills sees how people, ideas or events displayed in a particular way in the discourse of the news that affects meaning when received by the audience, with an emphasis on how the positions of the various social actors, the position of the idea, or event is placed in the news (Eriyanto, 2001, p. 201). News text shows women as objects of representation.

In some news, women are placed as "the objects of male desire". In other news, women are represented as factors causing corruption, disruption of society's norms, and other misbehaviors. This insensitive gender articulation further marginalizes the role and the importance of women towards contribution to building society and nation.

\section{Discussion and Conclusion}

Many Indonesian journalists are still not fully aware of gender complexity and its problematics. Based upon some observations and analyses on selected news published in Tribunnews.com, online media is failed to address women issue with fairness and empathy. The media actors (including reporters and editors) are not the parties who live up to our expectation to become agents of change, i.e. to open audience mind from lingering stereotype of patriarchal culture, discriminatory acts towards women, and women seen as socialites who embody the consumeristic and hedonistic way of life.

In other words, the power of patriarchy still dominates the news content and discourse that marginalizes women. Media fails to position women as actors with intelligible capacity and striking personas in news coverage and reporting. In advertisements, physical appearance of a woman, the 'so-called' outer beauty, is still primed as the main attraction.

The subordinate position of women in the news and advertisements is once again cementing some negative stereotypes about women's role and contribution for the advancement of gender justice and equality in media, specifically in journalism activity (Yusuf, 2004, p. 359). Overall, Tribunnews.com as one of the most powerful online media in Indonesia today is still legitimizing gender bias accepted as 'normal'. For example, the news of rape and corruption cases which portray women as the cause of the problem (Siregar, 2004, p. 358).

Based on the analyses above, Tribunnews.com cannot be classified as 'gender sensitive' online media yet since the number of female journalists employed is fewer than male journalists. Also, female journalists do not hold strategic positions in media management to issuing pro-women policies as well as to influence gender sensitive decision making.

Nevertheless, despite all the setbacks faced by women in media setting of Tribunnews.com, we could all agree with Mills (1997) that by adopting a feminist modified theory of discourse, one popularly recognized as "gender perspective journalism," 'the possibilities of negotiating with these discursive structures' and, later on, 'constructing scenarios for social change and subject positions for active women as agents,' (p. 103) are still achievable.

\section{Recommendations}

By looking closely at several news taken from Tribunnews.com discussed and analysed above, we come to several 
recommendations. Media should promote gender equality by taking deeper look at and incorporating gender perspective in its news. This will be achieved by setting media organizations to provide workshops and specific trainings on gender issues to all journalists and all managerial levels, in order to raise awareness of gender complexities and problems. Media owners should also check the balance of workers' composition between female and male journalists, and deliberately, with proper training and selection, install women in chief editor position. By applying this, the goal of setting the voices of women and men as equally represented in media will be within reach.

Media's balanced (not biased!) perspective towards women is also important not only for the sake of strengthening democracy, pluralism, and society's values, but as a healthier reflection of reality as well. In practice, the need to produce a gender sensitive code or regulation for journalists and media workers is also on the horizon. As for journalists, they need to be trained to recognize and to avoid reproducing or supporting certain stereotypes and prejudices against women as well as readily use non-sexist language in the writings. For media owners and managers, they should "promote gender-fair language in job advertisements in order to help achieving gender equality in recruitment processes" (Hodel, et. al., 2017), to provide more space for women to work with less discriminatory milieu and job desks in order to prevent them from being burnt-out and "to remain in journalism" (Reinardy, 2009), and to proportionally maintain equal voice between women and men in the media. Female journalists should also be more active to speak out gender justice and to put more female figures as agents of change in their writings.

\section{References}

Awuy, T. F. (2000). Bahasa Jurnalistik dan Gender. In A. Siregar, et al. (Eds.), Eksplorasi Gender di Ranah Jurnalisme Hiburan. Yogyakarta: Lembaga Penelitian Pendidikan Penerbitan Yogya (LP3Y).

Beauvoir, S. de. ([1949] 2011). Le deuxième sexe. Translated into English as The Second Sex. Original copyright by Éditions Gallimard, Paris. Translation copyright @ 2009 by Borde, C. and Malovany-Chevallier, S. New York: Vintage Books. [Online] Available: http://uberty.org/wp-content/uploads/2015/09/1949_simone-de-beauvoir-the-second-sex.pdf

van Bemmelen, S. (1992). Media Massa dan Perubahan Nilai Jender. In L. Setyawati \& A. Endang (Eds.), Media Massa dan Wanita: Kumpulan Makalah Seminar Nasional Media Massa dan Wanita. (pp. 59-78). Jakarta: FISIP UI and UNIFEM.

Branston, G., \& Stafford, R. (2010). The Media Student's Book. New York: Routledge.

Castells, M. (2010). The Rise of the Network Society. Second edition, with a new preface. Wiley-Blackwell: Malden, MA (USA) and Oxford (UK)

Eriyanto. (2001). Analisis Wacana: Pengantar Analisis Teks Media. Yogyakarta: LKiS.

Fallaize, E. (1998). Simone de Beauvoir: A Critical Reader. London and New York: Routledge.

Fourie, P. J. (ed.) (2007). Media Studies: Media History, Media and Society. South Africa: Juta and Company Ltd.

Grizzle, A. (Ed.). (2012). Gender-Sensitive Indicators for Media: Framework of Indicators to Gauge Gender Sensitivity in Media Operations and Content. Paris: United Nations Educational, Scientific and Cultural Organization (UNESCO). [Online] Available:

http://unesdoc.unesco.org/images/0021/002178/217831e.pdf (April 12, 2017)

Halloran, J. D. (1973). Mass media and society: the challenge of research: an inaugural lecture delivered in the University of Leicester, 25 October 1973

Handayani, T. \& Sugiarti. (2001). Konsep dan Teknik Penelitian Gender. Malang: Pusat Studi Wanita dan Kemasyarakatan Universitas Muhammadiyah Malang (UMM).

Hodel, L., Formanowicz, M., Sczesny, S., Valdrová, J. \& Stockhausen, L. von. (2017). Gender-Fair Language in Job Advertisements: A Cross-Linguistic and Cross-Cultural Analysis. Journal of Cross-Cultural Psychology, 48(3), 384-401. doi: http://journals.sagepub.com/doi/full/10.1177/0022022116688085

Kafiris, K. (ed.) (2005). The Gender and Media Handbook: Promoting Equality, Diversity and Empowerment. Nicosia (Cyprus): Mediterranean Institute of Gender Studies (MIGS).

Lievrouw, L. A. \& Livingstone, S. (Eds.). (2006) Handbook of New Media: Social Shaping and Social Consequences of ICTs. Updated Student Edition. London, Thousand Oaks, New Delhi: Routledge.

Lowery, S. A. \& DeFleur, M. L. (1995). Milestones in mass communication research: Media effects. (3rd edition). White Plains, NY: Longman.

Marvin, C. (1988). When Old Technologies Were New: Thinking About Electric Communication in the Late Nineteenth Century. Oxford: Oxford University Press.

Mills, S. (1997). Discourse. London and New York: Routledge

McLuhan, Marshall (1964). Understanding Media: The Extensions of Man (1st ed.). McGraw-Hill

Mosse, J. C. ([1993]1996). Gender dan Pembangunan. Translated into Indonesian from Half the World, Half a Chance: An Introduction to Gender and Development. Yogyakarta: Pustaka Pelajar.

Reinardy, S. (2009). Female Journalists More Likely to Leave Newspapers. Newspaper Research Journal, 30(3), 42-57. doi: http://journals.sagepub.com/doi/pdf/10.1177/073953290903000304

Sarwono, B. K. (2013). Saatnya Media Pro Perempuan: Perspektif Gender dalam Kajian Media. Jakarta: Lingkar Media.

Scannell, P. (2007). Media and Communication. London and New York: Routledge 
Schudson, M. (1981). Discovering The News: A Social History of American Newspapers. New York: Basic Books.

Siregar, A., et. al. (2000). Eksplorasi Gender di Ranah Jurnalisme dan Hiburan. Yogyakarta: LP3Y

Smith, D. (1990). Texts, Facts and Femininity: Exploring the Relations of Ruling. London: Routledge.

Soemandoyo, P. (1999). Wacana Gender \& Layar Televisi: Studi Perempuan dalam Pemberitaan TV Swasta. Yogyakarta: LP3Y-The Ford Foundation

Staiger, J. \& Hake, S. (Eds.) (2009). Convergence Media History. London and New York: Routledge

Sturken, M. \& Cartwright, L. (2001). Practices of Looking: An Introduction to Visual Culture. Oxford (UK): Oxford University Press.

Subono, N. I. (2003). Menuju Jurnalisme Berperspektif Gender. Jurnal Perempuan: Perempuan dan Media Issue, 28, 60-64. Jakarta: Yayasan Jurnal Perempuan

Tomagola, T. A. (1992). Citra Wanita dalam Iklan dalam Majalah Wanita Indonesia: Suatu Tinjauan Sosiologi Media. In Media Massa dan Wanita: Conference Proceeding. Depok: Proyek Studi Gender dan Pembangunan FISIP UI.

Sutrisno, M. \& Putranto, H. (Eds.). (2005). Teori-teori Kebudayaan. Yogyakarta: Kanisius.

Yusuf, I. A. (2004). Peningkatan kepekaan gender dalam jurnalisme. Jurnal IImu Sosial dan IImu Politik, 7(3), 351-376. doi: http://dx.doi.org/10.22146/jsp.11065

Walby, S. (1990). Theorizing Patriarchy. Oxford (UK): Basil Blackwell.

Wang, G., Servaes, J. \& Goonasekera, A. (Eds.) (2000). The New Communications Landscape: Demystifying Media Globalization. London and New York: Routledge.

Valdivia, A. N. (General Editor). (2013). The International Encyclopedia of Media Studies. Blackwell Publishing. DOI: 10.1002/9781444361506.wbiems169

\section{Source of pictures:}

Fig. 1: http://cdn2.tstatic.net/belitung/foto/bank/images/ilustrasi-foto_20151006_122034.jpg

Fig. 2: http://static6.depositphotos.com/1062035/625//950/depositphotos_6259299-stock-photo-lady-in-a-luxury-car.jpg

Fig. 3: http://cdn2.tstatic.net/makassar/foto/bank/images/tato-menteri-susi-pudjiastuti.jpg

\section{Original sources of news analysed in this article, with hypertext links:}

On the issue of rape and sexual harassment:

http://www.tribunnews.com/regional/2015/08/11/selaput-dara-mahasiswi-korban-perkosaan-sepasang-kekasih-tidak-rusak

Tuesday, August 11, 2015 (23:11 WIB)

Editor: Sugiyarto

Original Source: Surya

http://www.tribunnews.com/regional/2016/03/04/2-siswi-smp-digilir-6-remaja-semalaman-paginya-langsung-diantar-ke-sekolah

Friday, March 4, 2016 (23:29 WIB)

Editor: Sugiyarto

Original Source: Surya

http://www.tribunnews.com/regional/2015/02/11/tersangka-perkosaan-siswi-smp-saya-hanya-disuruh-ngrasain-katanya-dia-cabe-cabean

Wednesday, Februari 11, 2015 (21:37 WIB)

Editor: Sugiyarto

Original Source: Sriwijaya Post

\section{On the issue of women and corruption}

http://medan.tribunnews.com/2015/07/23/korupsi-dan-perempuan-di-balik-korupsi

Thursday, July 23, 2015 (16:34 WIB)

Writer: T. Agus Khaidir

Editor: T. Agus Khaidir

Source: Tribun Medan

http://aceh.tribunnews.com/2015/11/17/perempuan-dalam-pusaran-korupsi

Tuesday, November 17, 2015 (14:04 WIB)

Editor: Bakri

Source: Serambi Indonesia

http://www.tribunnews.com/nasional/2015/04/27/koruptor-kerap-manfaatkan-istri-simpanan-untuk-tampung-uang-hasil-korupsi

Monday, April 27, 2015 (18:23 WIB)

Editor: Yulis Sulistyawan

\section{On the issue of body-image in advertisements and politics}

http://www.tribunnews.com/kesehatan/2010/08/10/payudara-besar-perempuan-inggris-hampir-jadi-pembunuh 
Tuesday, August 10, 2010 (10:01 WIB)

Editor: Widiyabuana Slay

http://bali.tribunnews.com/2015/05/04/mau-kencan-dengan-wanita-cantik-naik-mobil-eksotis

Monday, May 4, 2015 (18:05 WIB)

Editor: Ida Ayu Made Sadnyari

Source: Kompas.com

http://www.tribunnews.com/kesehatan/2015/02/15/perempuan-cantik-ini-minta-jokowi-menyikapi-ancaman-bahaya-rokok

Sunday, Februari 15, 2015 (10:39 WIB)

Writer: Rahmat Patutie

Editor: Gusti Sawabi

http://www.tribunnews.com/nasional/2015/10/26/pernah-merokok-dan-punya-tato-menteri-susi-tetap-paling-disukai-masyarakat Monday, October 26, 2015 19:39 WIB

Writer: Srihandriatmo Malau

Editor: Hasanudin Aco

\section{On the issue of violence towards female migrant worker}

http://jateng.tribunnews.com/2015/08/22/saerah-tki-cantik-asal-grobogan-tewas-dihajar-majikannya-di-yordania

Saturday, August 22, 2015 (20:04 WIB)

A report from Tribun Central Java region journalist, Puthut Dwi Putranto

Editor: Iswidodo

Source: Tribun Jateng 